\title{
Проблемы хранения технотронных документов в архивах Тувы
}

\author{
Салимаа С. Ховалыг \\ Тувинский государственный университет, Российская Федерация
}

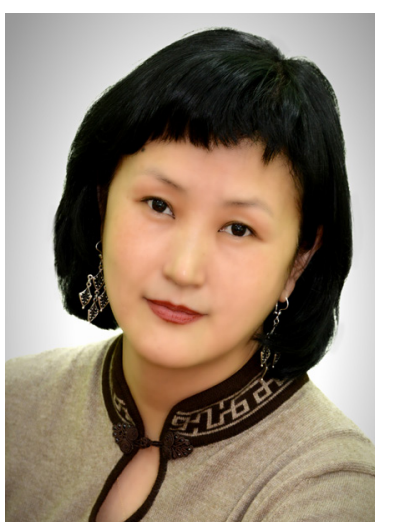

В статье анализируются проблемы организации хранения технотронных документов (имеющих техническое происхождение) в архивах Тувы. Источниковой базой исследования стали технотронные документы Национального (до 07.04.2020 г. - Государственного) архива Республики Тыва, Национального музея им. Алдан-Маадыр Республики Тыва, а также органов государственной власти и управления Тувы. Огромный пласт кинофоно-фотодокументов был создан в результате документальной и художественной фотосъемки, документального и художественного кинодокументирования. Также в архивах Тувы хранятся электронные документы.

Хранение фотодокументов в главном архиве республики организовано аналогично другим архивам кино-фото-документов. Но здесь есть ряд проблем: отсутствие четкого фондирования (например, часть фотодокументов объединены с фондами личного происхождения); проблемы соблюдения температурно-влажностного режима хранилищ для сохранности фото- и фонодокументов; неправильное хранение негативов; проблемы создания страховых копий, фонда пользования; проблемы оцифровки фото- $и$ фонодокументов; проблемы хранения электронных документов. Здесь, очевидно, необходимо организовать Центр хранения технотронных документов.

Актуальная задача Национального музея им. Алдан-Маадыр Республики Тыва - составление каталога, реестра фотодокументов фотофонда. Для архивов органов государственной власти и управления Тувы, в которых сегодня производится достаточно много аудиовизуальных документов, важная проблема - организация их правильного хранения.

Ключевые слова: Тува; Тувинская Народная Республика; архивный документ; технотронные документы; аудиовизуальные источники; Государственный архив Республики Тыва; Национальный архив Республики Тыва; Национальный музей Республики Тыва

\section{Для цитирования:}

Ховалыг С. С. Проблемы хранения технотронных документов в архивах Тувы // Новые исследования Тувы. 2020, № 2. C. 63-74. DOI: www.doi.org/10.25178/nit.2020.2.4

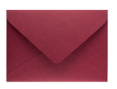

Ховалыг Салимаа Сергеевна - кандидат исторических наук, доцент, проректор по учебной работе и качеству, доцент кафедры всеобщей истории, археологии и документоведения, исторического факультета Тувинского государственного университета. Адрес: 667000, Россия, г. Кызыл, ул. Ленина, д. 36. Тел.: +7 (39422) 2-35-42. Эл. адрес: salimaa@mail.ru

ORCID ID: 0000-0002-2509-2402

Khovalyg Salimaa Sergeevna, Candidate of History, Associate Professor, Vice-rector for Academic Affairs and Quality, Associate Professor of the Department of General History, Archeology and Documentation, History Department, Tuvan State University. Postal address: 36 Lenina St., 667000, Kyzyl, Russia. Tel.: +7 (39422) 2-35-42. E-mail: salimaa@mail.ru 


\title{
Preserving technotronic documents in the archives of Tuva
}

\author{
Salimaa S. Khovalyg \\ Tuvan State University, Russian Federation
}

\begin{abstract}
The article addresses issues of managing storage of technotronic documents (i.e. those of technical origin) in Tuva's archives. It is a study of technotronic documents preserved in the collections of the National Archives (prior to 07.04.2020 - State Archives) of the Republic of Tuva, as well as at the Aldan Maadyr National Museum, and of institutions of regional government and administration. A large collection of video-, phono- and photodocuments came into being as a result of years of doing documentary and artistic photo and video shoots. Tuvan archives also preserve a number of electronic documents.

At the main archive of the republic, photo storage is organized along the same lines as at other archives of video- and photodocuments. However, a number of problems persist, such as the absence of stringent classification (some of the photos are included in personal collections); temperature and moisture control for better preservation of these type of items; wrong regime of storage for photographic negatives; making reserve copies; setting up the copies' collection; digitalizing photos and phonodocuments; and storing electronic documents. An urgent priority is to set up a Center for Storing Technotronic Documents. Another urgent challenge, the one for the Aldan Maadyr National Museum of the Republic of Tuva, is to organize a catalog and register of the photographic documents in their photo collection. Meanwhile, the bodies of regional government and administration of Tuva, where a slew of audiovisual documents are now produced every year, an important challenge is to organize their storage correctly.
\end{abstract}

Keywords: Tuva; Tuvan People's Republic; archival documents; technotronic documents; audiovisual sources; State Archives of the Republic of Tuva; National Archives of the Republic of Tuva; National Museum of the Republic of Tuva

\section{For citation:}

Khovalyg S. S. Preserving technotronic documents in the archives of Tuva. The New Research of Tuva, 2020; 2: 63-74. (In Russ.). DOI: www.doi.org/10.25178/nit.2020.1.4

\section{Введение}

Целью статьи является анализ проблем организации хранения технотронных документов в архивах Тувы. Для исторической науки технотронное архивоведение является сравнительно молодым направлением. Тем не менее, разные виды технотронных документов неоднократно становились объектом научного изучения.

В истории научного исследования технотронных документов можно выделить три больших этапа: конец XIX века - 1950-е гг., когда рассматриваются вопросы создания архивохранилищ кинодокументов, наделения кинодокументов статусом документа и включения их (например, грампластинок) в состав документации, оптимальных условий хранения документов на пленочном носителе (Болтянский, 1926); вторая половина 1950-х гг. - 1990-е гг., когда труды характеризуются постановкой теоретических проблем архивоведения документов на нетрадиционном носителе (Кузин, 1960; Митяев, 1964; Автократов, 1978); и, наконец, третий - нынешний - этап, ведущий отсчет с конца 1990-х гг. Здесь следует отметить В. М. Магидова, который собственно, говоря, и стал основоположником одного из перспективных направлений отечественного документоведения - технотронной документалистики и технотронного архивоведения (Магидов, 1984).

Проблемы архивоведения аудиовизуальных, научно-технической документации, электронных документов в контексте общих теоретических и прикладных проблем отечественного архивоведения предмет научного исследования ученых Ф. А. Гедровича (Гедрович, 1998), Т. И. Хорохординой (Хорхордина, 2003), Г. Н. Ланского (Ланской, 2014), специалистов архивных служб Р. М. Моисеевой (Моисеева, 2006), Н. А. Калантаровой, Т. А. Алексеевой (Калантарова, Алексеева, 2011). Труды историков, исследовавших разные виды технотронных документов в качестве исторических источников, нами не рассматриваются. 
Изучение регионального опыта организации работы с технотронными документами в архивах Тувы проводится специалистами кафедры документоведения и архивоведения Тувинского государственного университета (далее - ТувГУ), в том числе автором данной статьи, с 2015 г. и получило отражение в статьях, тезисах научно-практических конференций разного уровня. Например, в соавторстве с А. А. Бадыназын мы анализировали проблемы организации, использования и хранения технотронных документов в органах государственной власти (Ховалыг, Бадыназын, 2015); в соавторстве с Ч. Б. Шактар-оол разрабатывали проблемы организации хранения и использования аудиовизуальных документов в Национальном архиве Республики Тыва (Государственном архиве Республики Тыва, ГА РТ ${ }^{1}$ ) (Ховалыг, Шактар-оол, 2018). В 2018 г. в честь столетия архивной службы Российской Федерации в Туве в том числе была проведена научно-практическая конференция «Роль и значение архивов и архивных документов в сохранении исторической памяти народа», на которой были представлены доклады исследователей ТувГУ: исследование организации использования технотронных документов в органах исполнительной власти (Ховалыг, Монгуш, 2018), описано хранение кино-документов в ГА РТ (Шактар-оол, 2018), а также представлен опыт обобщения истории и современного состояния технотронных архивов Российской Федерации (Ховалыг, 2018).

Новизна данной статьи заключается в том, что впервые проводится обобщение регионального опыта, накопленного архивными службами по работе с разными видами технотронных документов. Из подобных работ нам известна только статья о фотодокументах муниципальных архивов Республики Хакасии, раскрытых в контексте организации фондов личного происхождения (Маковкина, 2016).

Теоретической основой исследования стали ключевые принципы историзма и компаративный исторический метод, позволившие провести всесторонний анализ использования технотронных документов в Туве. Специальные архивоведческие методы позволили провести анализ принципов комплектования, организации экспертизы ценности, обеспечение сохранности и использования технотронных документов в архивах в зависимости от их вида и происхождения.

Источниковой базой исследования стали технотронные документы Государственного архива Республики Тыва, Национального музея им. Алдан-Маадыр Республики Тыва, а также органов государственной власти и управления Тувы.

\section{Технотронные документы}

Сегодня в отечественной науке сложилось несколько концепций «технотронного документа». Мы остановимся только на одной, которая опирается на источниковедческую концепцию, сформулированную учеными Историко-архивного института Российского государственного гуманитарного университета (ИАИ РГГУ). Концепция приобрела свое оформление в трудах В. М. Магидова и была продолжена его коллегами и учениками: Ф.А. Гедрович (Гедрович, 1998), Л.Ф. Малышева (Гедрович, Малышева, 2005) и др.

В. М. Магидов пишет, что «термин “технотронный” был зафиксирован в 1992 г. в информационносправочной литературе как связанный с развитием науки, в особенности ЭВМ и связи» ${ }^{2}$. Ранее в исторической науке, в частности, в документоведении и архивоведении, для обозначения документов, имеющих техническое происхождение, использовались термины «машиночитаемый документ» (МЧД), «документ на машинном носителе» (ДМН). В этой связи, государством были изданы государственные отраслевые стандарты по организации работы с машиночитаемыми документами. Однако, как справедливо отмечает В. М. Магидов, такая узкая трактовка документов, имеющих нетрадиционное происхождение довольно узка, и требует своего переосмысления³

\footnotetext{
${ }^{1}$ В связи с тем, что переименование архива пришлось на период предпечатной подготовки статьи (7 апреля 2020 г.) далее мы сохраняем в тексте старое название "Государственный архив Республики Тыва" и аббревиатуру "ГА РТ". - ред.

Editors' note: Since the Archives was renamed while editorial work on the article was already under way (April 7, 2020), we have preserved at some places the institution's old name - "State Archives of the Republic of Tuva".

${ }^{2}$ Магидов, В. М. (2004) Технотронные архивы и документы в терминологическом ракурсе / Технотронные архивы в современном обществе: наука, образование, наследие (Материалы научно-практической конференции, посвященной 10-летию факультета технотронных архивов и документов) [Электронный ресурс] // Историкоархивный институт. Факультет технотронных архивов и документов. URL: http://ftad.ru/library/ftad10/19.shtml (дата обращения: 03.04.2018).

${ }^{3}$ Там же.
} 
Суть источниковедческой концепции заключается в том, что В. М. Магидов, раскрывая понятие «технотронный документ», не только оценивает этот вид документа как исторический источник, но и как документ, жизненный цикл которого связан с управленческими процессами организации, и который затем после проведения экспертизы ценности передается на постоянное архивное хранение.

По В. М. Магидову, технотронный документ является результатом технического документирования (кино-фото-фоно-документирование, перфорирование, кодирование информации, видео-документирование и т. д.), также он содержит документированную информацию. Такая трактовка технотронного документа позволила расширить его рамки за пределы технического происхождения. К нему могут быть отнесены все виды научно-технической документации, включая проектно-сметные документы, чертежи, отчеты о научно-исследовательской работе; производственные документы, сопровождающие создание не только зданий и сооружений, но и все виды техники, когда-либо создаваемые человеческими руками, имеющие предварительный план, наброски и прочее. И еще один компонент, который можно учесть при классификации технотронных документов, это не только способ документирования, но и документная среда как носитель документированной информации. По этому критерию можно выделить магнитные документы (ленты, диски, карты), оптические, магнитооптические и электронные документы.

Таким образом, отметим, что «технотронный документ» в источниковедческой интерпретации остается собирательным понятием. С одной стороны, он объединяет документы, имеющие техническое происхождение. А с другой стороны, технотронные документы трактуются как источники по истории развития науки и техники. Также надо иметь в виду, что сам термин «технотронный документ», в силу своей «собирательности» не имеет юридического закрепления. И, следовательно, при работе с технотронными документами, возникают определенные проблемы.

\section{Технотронные документы фондов Государственного архива Республики Тыва}

В Государственном архиве Республики Тыва, созданном в 2011 г., история которого восходит к Государственному архиву Тувинской Народной Республики 1930 г., хранятся документальные материалы за период 1715-2011 гг. Всего здесь насчитывается 856 фондов с общим числом единиц хранения 164715 (Путеводитель по фондам ..., 2012: 9), фотодокументов с 1917 г. по 2010 г. более 4521 тыс. единиц хранения (там же: 341).

ГА РТ работает с фотодокументами в соответствии с «Правилами организации хранения, комплектования, учета и использования документов Архивного фонда Российской Федерации и других архивных документов в государственных и муниципальных архивах, музеях и библиотеках, организациях Российской академии наук», введенными в 2007 г. ${ }^{1}$

Архив начал комплектоваться фотодокументами с 1989 г. (Ховалыг, Шактар-оол, 2018: 323). Во время проведения экспертизы ценности при приеме фотодокументов на постоянное хранение специалисты обязаны проверить идентичность изображения на негативе с позитивным отпечатком и аннотацией. Более того, при проведении экспертизы ценности кинофотофонодокументы и видеофонограммы при необходимости просматриваются и прослушиваются. При их анализе определяется степень полноты повторения информации, периодичность образования документов с повторяющейся информацией². Каждый документ должен быть упакован в первичную, а затем - во вторичную упаковку. Первичная упаковка имеет прямой контакт с документом и защищает его от пыли и влаги, а вторичная упаковка предохраняет документ и первичную упаковку от механических повреждений, света и других воздействий окружающей среды ${ }^{3}$. Кроме того, необходимо проставить архивный номер единицы хранения на

\footnotetext{
${ }^{1}$ Правила организации хранения, комплектования, учета и использования документов Архивного фонда Российской Федерации и других архивных документов в государственных и муниципальных архивах, музеях и библиотеках, организациях Российской академии наук, утвержденные Приказом Министерства культуры РФ от 18.01.2007 № 19.

${ }^{2}$ Основные правила работы государственных архивов с кинофотофонодокументами были утверждены Главархивом СССР 21.05.1979 (с изм. от 29.12.2001) [Электронный ресурс] // Справочно-правовая система КонсультантПлюс. URL: http://www.consultant.ru/cons/cgi/online.cgi?req=doc \&base=ESU\&n=44087\#01871841984079 0612 (дата обращения 10.01.2020).

${ }^{3}$ ГОСТ 7.65-92. Государственный стандарт Союза ССР. Система стандартов по информации, библиотечному и издательскому делу. Кинодокументы, фотодокументы и документы на микрофильмах. Общие требования к архивному хранению: издание официальное: утвержден и введен в действие Постановлением Комитета
} 
негативе, в конверте, в котором будет храниться негатив, и на позитивном отпечатке. Фотодокументы хранятся и учитываются по видам фотодокументов: черно-белые и цветные негативы, позитивы, фотоальбомы (Калантарова, Алексеева, 2011).

Традиционно в архивоведении фотодокументов выделяют три вида фонда личного происхождения: личные фонды фотографов и фотокорреспондентов; личные фотоколлекции; личные фотоархивы граждан. В ГА РТ фотодокументы (негативы и позитивы), образовавшие в результате профессиональной деятельности приняты из личных архивов фотографов и фотокорреспондентов, таких как: Ю. Ф. Бармин, П. М. Гольцов, А. А. Зайцев, В. П. Ермолаев, Ю. А. Косарьков, В. Г. Кудрявцев, А. И. Мельников, О. Д. Охемчик, Г. П. Сиротин, В. Н. Савиных, В. А. Шайфулин и др. (Путеводитель по фондам ..., 2012 : 343). Однако фотодокументы не распределены по фондам личного происхождения.

Хранение фотодокументов в ГА РТ организовано аналогично другим архивам кино-фото-документов, в частности также, как и в Российском государственном архиве кинофотодокументов (далее - РГА КФД). Число фотографий в альбомах ГА РТ разное - от 63 до 219 (в РГА КФД число фотографий колеблется от 1-2 до 900, см.: Калантарова, Алексеева, 2011: 75).

В фонде Р-101 хранятся 13 коллекций фотоальбомов, принадлежавших российскому этнографу и музейному работнику, исследователю Тувы и тувинского народа Владимиру Петровичу Ермолаеву, где собраны снимки автора, представляющие историю Тувы первой половины XX века. Всего в фотоальбомах насчитывается 82 фотографии.

В соответствии с требованиями фотографии в альбоме должны маркироваться внутренней нумерацией в валовом порядке (слева направо, сверху вниз). Учет фотографий в альбоме ведется по внутренней описи, где необходимо указывать: архивный номер, название альбома, количество листов, снимков (фотографий) (Калантарова, Алексеева, 2011: 75). Однако по сравнению с фотодокументами документами РГА КФД в ГА РТ отсутствует описание каждой фотографии и альбома в целом.

Коллекции тринадцати фотоальбомов были оцифрованы в сентябре 2011 г. Оцифрованные фотоальбомы В. П. Ермолаева также хранятся на внешнем накопителе Expansion Drive, в сейфе ГА РТ. Фотографии пронумерованы, аннотации к фотографиям не обнаружены.

Поскольку при оцифровании документы преобразовываются в электронный вид, то здесь работники архива столкнулись с проблемой определения наиболее оптимального формата хранения электронной копии архивного документа, в том числе фотодокумента, графического документа. Проблему унификации и подбора наиболее подходящего формата электронных копий архивных фотодокументов уже несколько лет пытаются решить не только в России, но и за рубежом. И сотрудники архивов, и исследователи в научных публикациях, тематических блогах, научно-практических конференциях делятся опытом и предлагают разные форматы. И. Е. Хворова, анализируя наиболее распространенные форматы хранения электронных копий архивных документов, пишет, что наибольшее распространение у архивистов получили форматы TIFF и JPEG. Формат TIFF позволяет сохранить фотодокумент в электронном виде практически без потери качества (Хворова, 2017: 24).

Изображения ГА PT сохранены в формате JPEG. К сожалению, несмотря на преимущества этого формата в виде высокой степени сжатия, при этом одновременно утрачивается качество изображения, что является недопустимым для создания страховой копии фотодокумента. В связи с этим, И. Е. Хворова отмечает, что JPEG нельзя использовать как промежуточный формат при обработке изображений. В JPEG допустимо сохранять лишь окончательный вариант (там же). Сотрудники архивных служб с недавних пор обсуждают формат JPEG 2000, который не получил широкого распространения. Специалисты из Digital Preservation Coalition (Коалиции цифровой сохранности, Великобритания) после тестирования формата JPEG 2000 сделали вывод о явных преимуществах данного формата перед другими ${ }^{1}$.

Следующей проблемой является обеспечение сохранности фотодокументов: соблюдение режима хранения, проведение реставрации, создание страховой копии и прочие. Контроль за температурновлажностным режимом в ГА РТ осуществлялся с помощью контрольно-измерительного прибора - гигрометра психрометрического типа ВИТ-1 и сведения фиксировались в журнале регистрации температурно-влажностного режима.

стандартизации и метрологии СССР от 27.03.92 № 296: введен впервые: дата введения: 1993-01-01 / разработан и внесен Главным архивным управлением СССР, Техническим комитетом 191. М. : Изд-во стандартов, 1992. С. 4.

${ }^{1}$ Butch Lazorchak (2011) A Fine View at the Summit of JP2 (Прекрасный вид на Саммит JP2) [Электронный ресурс] // Library of Congress. URL: https://blogs.loc.gov/thesignal/2011/06/a-fine-view-at-the-summit-of-jp2/ (дата обращения 10.01.2020). 
Напоминаем, что в соответствии с ГОСТ 7.65-92 каждый документ должен быть упакован в первичную, а затем - во вторичную упаковку. Так, например, в фонде 64 «Праздничная демонстрация трудящихся г. Кызыла, посвященная 01 Мая» хранятся фотоснимки, снятые фотографом республиканского архива К. Х. Очуром со дня праздничной демонстрации трудящихся г. Кызыла 1 мая 1988 г. Фотодокументы хранятся в первичной, а затем во вторичной упаковках. Первичная упаковка - конверт 32,1×23,2, на котором имеется печать с номером фонда, описи и единиц хранения, внутри которой хранятся 11 конвертов, где справой стороны прописаны порядковые номера. Размер конверта $16,2 \times 11,5$ см. В конверте № 1 с размером 12,1×9,1 см имеется 4 фотографии. На каждой фотографии с задней стороны зафиксированы номер фонда, описи и единицы хранения. Также внутри конверта находится конверт с размером, где также справой стороны имеется порядковый номер конверта, размер которого 10,3×7,4 см. Вторичная - коробка из картона 23,4×33,1 см., где прописаны номер фонда, описи и единиц хранения.

Однако три негатива с форматами: 3,9×3,5 см, 3,9×3,5 см и 7,5×3,5 см. хранятся в одном конверте, что является нарушением требований. Каждый негатив должен иметь индивидуальный пакет, а если по каким-то причинам необходимо в один пакет поместить несколько негативов, то они должны быть переложены промежуточными листами бумаги ${ }^{1}$.

В целях закрепления места хранения и поиска архивных документов в хранилищах составлены пофондовые и постеллажные топографические указатели. Топографические указатели составлены в карточной форме. Один экземпляр топографических указателей хранится у начальника государственного учета и обеспечения сохранности архивных документов, второй - в архивохранилище. Например, карточка фондов (фотодокументы) имеет графы: дата первого поступления фонда, дата получения карточки фонда, архивное управление при Совете Министров Тувинской АССР, местонахождение фонда, категория - номер фонда, крайние даты каждого названия фонда, название фонда, объем фонда на 01 января, годы, описанные единицы хранения, неописанные единицы хранения, микрофильмировано единиц хранения.

Хуже обстоит дело в ГА РТ с организацией хранения фонодокументов. Фонодокумент - это аудиовизуальный документ на ленточном или дисковом носителе, содержащий звуковую информацию² . Для этого необходимо специально оснащенное хранилище, но в связи с нехваткой дополнительных помещений ГА РТ не может пока выделить для него площадь. Также архив соответственно не прилагает усилий по выявлению организаций - источников комплектования фонодокументов, хотя в Туве имеется несколько организаций, которые могли бы стать потенциальными источниками комплектования, передающими фонодокументы на постоянное хранение в архив. И это относится не только к негосударственным звукозаписывающим студиям, но и к тувинскому региональному отделению всероссийского телерадиоканала «Россия» - ВГТРК «Тыва», чья история началась еще в 1960-е годы.

Тем не менее, надо подчеркнуть, что архив принимает на постоянное хранение документы после прекращения функционирования организации источника-комплектования. Так, например, были приняты фонодокументы Палаты представителей Великого Хурала за 2002-2009 гг. Однако хранятся они как документы на бумажной основе. Хранятся аудиокассеты в сейфе. Первичная упаковка - конверт размером 32,1×23, 1 см, внутри конверта имеется аудиокассета на обложке, которой прописано «Запись заседания Конституционной комиссии РТ» 2002 г. Кассета № 1. Сторона «А»- конституционная комиссия. Сторона «Б» - «10:00 - _//_. Вторичная: коробка из картона с размером 23,4×33,1 см.

На основании постановления Правительства Республики Тыва № 614 от 17.12.2009 г. «О ликвидации государственного учреждения “Тывакиновидеоцентр”», Указа Председателя Правительства РТ от 23.11.2009 г. № 261 «О передаче штатных единиц ГУ “Тывакиновидеоцентр” Государственному архиву РТ в 2009 г. были переданы фильмофонд учреждения и 4 штатные единицы сотрудников. Всего было передано кинодокументов - 2223 единиц учета, 18236 единиц хранения. Одновременно было передано здание бывшего киновидеоцентра, требующее капитального ремонта. Кинодокументы на 35 миллиметровой пленке в архив не переданы по описи сдачи-передачи, они переданы с каталогом фильмофонда ГУ «Тывакиновидеоцентр», где отражены художественный и документальный фильмофонды. Аудиовизуальные документы ГУ «Тывакиновидеоцентр» хранятся в составе фондообразователя.

\footnotetext{
${ }^{1}$ Карский, И. М. (2003) Некоторые аспекты реставрации фотодокументов [Электронный текст] // Российский государственный архив кино-фото-документов. URL: http://www.rgakfd.ru/doklady-soobshhenija/karskynekotorye-aspekty-restavracii-fotodokumentov (дата обращения 22.12.2019).

${ }^{2}$ ГОСТ 7.65-92. (ИСО 5127-11-83). Межгосударственный стандарт. Система стандартов по информации, би-
} 
Сотрудники отдела государственного учета и обеспечения сохранности архивных документов ГА РТ, выполняя план, копировали редкие художественные и документальные фильмы о Туве. Авторы и режиссеры фильмов не указаны. В ГА РТ хранятся такие художественные фильмы: «Люди голубых рек» (1959 г., Ленфильм); «Дерсу Узала» (1957 г., СССР - Япония); «Танец орла» (1975 г., Свердловская киностудия); «След росомахи» (1978 г., Ленфильм); «Злой дух Ямбуя» (1977 г., киностудия им. Горького); «Гадание на бараньей лопатке» (1988 г., Рижская киностудия); «60 беглецов» (1991 г., Свердловская киностудия, на тувинском языке).

Копирование художественных и документальных фильмов производилось следующим образом: старым оборудованием «Тывакиновидеоцентра» включали фильмы для отображения на экране и снимали с экрана, то есть вели видеозапись, встроенную в функции цифровых фотоаппаратов. Очевидно, что подобное «копирование» нельзя назвать правильным. Полученные видеофайлы хранятся в папках «Художественные фильмы», «Документальные фильмы» на локальном диске (D) персонального компьютера начальника отдела государственного учета и обеспечения сохранности архивных документов, также дублированные файлы фильмов хранятся на внешнем жёстком диске, в сейфе. Но фильмы не сохранены на CD-диске, и не составлены описи -передач, не хранятся в архивохранилищах. Оригиналы фильмов хранятся в архивохранилище ГА РТ.

Так, изучение организации хранения фото- и фонодокументов в Государственном архиве Республики Тыва позволило сформулировать ряд проблем:

- отсутствие четкого фондирования (например, часть фотодокументов объединены с фондами личного происхождения);

- проблемы соблюдения температурно-влажностного режима хранилищ для сохранности фото- и фонодокументов;

- неправильное хранение негативов;

- проблемы создание страховых копий, создание фонда пользования;

- проблемы оцифровки фото- и фонодокументов;

- проблемы хранения электронных документов.

Несмотря на наличие проблем, которые вызваны недостаточностью финансовых средств, руководство Государственного архива и Министерство культуры Республики Тыва, которому архив подчинен, пытаются найти решение. В частности, в 2017 г. с Росархивом (федеральным архивным агентством) велись переговоры о том, что Росархив рассмотрит заявку министерства культуры Тувы на приобретение оборудования Государственному архиву Тувы для перевода архивных документов в электронный формат и проведения оцифровки описей фондов Госархива за счет федеральных средств. Но спустя три года до сих пор ситуация не разрешена.

\section{Технотронные документы в архивах отдельных организаций}

За последние несколько лет нами было изучено несколько ведомственных архивов на предмет организации хранения и использования технотронных документов. В частности, фонды Национального музея им. Алдан-Маадыр Республики Тыва, архивы органов государственной власти и управления. В них хранятся в основном следующие типы и виды технотронных документов: фотодокументы (чаще всего представленные фотоотпечатками, т. е. фотографии, распечатанные на фотобумаге), видеодокументы на пленочном носителе, фонодокументы, как результат документирования заседаний, совещаний разного уровня, к сожалению зачастую перезаписываемые при необходимости еще во время оперативного хранения документов. Здесь надо отметить, что копирование проводилось в процессе воспроизводства фонодокумента, и сохраняемые как электронные документы в виде отдельных файлов. Последний вид документов сегодня приобрел наибольшую популярность в силу развития цифровых технологий в сфере документирования разных процессов.

блиотечному и издательскому делу. Аудиовизуальные документы. Основные термины и определения (1996): издание официальное: утвержден и введен в действие: Межгосударственным Советом по стандартизации, метрологии и сертификации (протокол № 8-95 от 10-12 октября 1995 г.). введен впервые: дата введения: 199707-01 / разработан Научно-исследовательским центром технической документации (РНИЦКД) Государственной архивной службы России и ТК 191 «Научно-техническая информация, библиотечное и издательское дело» внесен : Госстандартом России. М. : Изд-во стандартов. С. 2. 
В 2009 г. в Национальном музее им. Алдан-Маадыр РТ был создан фотофонд. Наиболее ценной коллекцией фотофонда Национального музея им. Алдан-Маадыр РТ являются фотодокументы основателя музейного дела В. П. Ермолаева, а это более 4356 единиц стеклянных и пленочных фотонегативов (Айыжы, Мандан-Хорлу, Монгуш, 2019ab). Здесь хранятся фотодокументы и других известных фотографов Тувы. Например, Ю. А. Косарькова, В. Н. Савиных, М. Ч. Чооду, В. М. Балчый-оола, Ш. Ш. Биче-оола, С. М. Еловикова, О. Сморжевской, С. Н. Шапиро, Н. Ф. Никифорова и других.

Помимо фотоотпечатков в фотофонде музея хранятся негативы фотодокументов. Музейными сотрудниками фотонегативы В. П. Ермолаева были классифицированы по содержанию на 24 группы. Число негативов в каждой группе разное от 2 до 1498 единиц.

Качество негативов фотодокументов В. П. Ермолаева остается высоким и сегодня музей получает хорошие фототпечатки. Качество негатива связано с материалом и способом создания фотодокумента (они были созданы путем дагерротипии - способом, основанном на использовании свойств счеточувствительности йодистого серебра, который обеспечивает столь высокое качество получаемого фотонегатива). Поскольку стекло является довольно хрупким материалом, данная коллекция негативов относится к особо ценным документам, доступ к которым строго ограничен. Однако с началом процесса оцифровки фотодокументов, в музее была проведена интенсивная работа по переводу хорошо сохранившихся негативов в электронный формат. Здесь сотрудники музея столкнулись с очередной проблемой, которая связана с процессом организации и проведения экспертизы ценности технотронных документов: наличие всех требуемых материалов и дополнительных документов в виде аннотации, которая должна включать не только данные фотографа, но и описание места, времени съемки, краткую характеристику объектов съемки, участников фотодокументирования. Негативы В. П. Еромолаева не имели аннотаций, в связи с чем необходимо было проведение работ по атрибуции, описанию, разработке справочника-путеводителя по фотодокументам основателя музейного дела в Туве. Составление каталога, реестра фотодокументов фотофонда Национального музея им. Алдан-Маадыр РТ до сих пор остается актуальной задачей.

Технотронные документы принимаются на хранение и в архивах органов государственной власти и управления: Верховным Хуралом (парламентом) Республики Тыва, архивом Правительства Республики Тыва, архивом мэрии г. Кызыла, архивами администраций ряда муниципальных образований Тувы и др. Здесь помимо аудиовизуальных документов происходит накопление электронных документов.

Документы хранятся не столько в виде оптических дисков, сколько во внешних и внутренних устройствах хранения данных. К сожалению, недостаточный опыт организации хранения электронных документов в ведомственном архиве приводит к тому, что организациями не обеспечиваются все необходимые условия, предусмотренные ГОСТ Р 54989-2012/ISO/TR 18492:2005 «Обеспечение долговременной сохранности электронных документов» ${ }^{1}$ В нем говорится о том, что при создании условий для долговременной сохранности электронных документов особое внимание следует уделить вопросу носителей, также, как и для других видов технотронных документов. Помимо качества самого носителя, который может быть представлен в виде магнитной ленты, магнитного, магнитооптического диска, оптического диска, необходимо учитывать оборудование, при помощи которого будет осуществлено воспроизводство информации. ГОСТ устанавливает организацию хранения с учетом необходимых принципов, связанных именно с возможностью воспроизводства информации электронного документа: читаемость, интерпретируемость, идентифицируемость, доступность, понятность, и, конечно же, аутентичность электронных документов.

В архивах органов государственной власти и управления технотронные документы хранятся, как документы на традиционном носителе, поскольку их предварительно конвертируют. Например, в архивах Правительства Республики Тыва, Верховного Хурала, аудиозаписи и видеозаписи протоколов заседаний транскрибируются в текстовый вид, следовательно, хранятся как бумажные документы. Од-

\footnotetext{
${ }^{1}$ ГОСТ P 54989-2012/ISO/TR 18492:2005. Национальный стандарт Российской Федерации. Обеспечение долговременной сохранности электронных документов: утвержден и введен в действие Приказом Федерального агентства по техническому регулированию и метрологии от 17.09.2012 г. № 325-ст.: введен впервые: дата введения: 2013-05-01 / подготовлен ООО «Электронные Офисные Системы (проектирование и внедрение)» и внесен Техническим комитетом по стандартизации ТК 459 «Информационная поддержка жизненного цикла изделий». М.: Стандартинформ, 2013. 19 с. [Электронный ресурс] // Электронный фонд правовой и нормативно-технической информации. URL: http://docs.cntd.ru/document/1200096286 (дата обращения 20.01.2020).
} 
нако, к сожалению, не уделяется должное внимание к организации хранения самого аудиовизуального документа. В настоящее время аудиовизуальные документы в ведомственных архивах органов государственной власти и местного самоуправления хранятся в двух видах: в виде записи на оптическом диске и в виде файла на жестком диске компьютеров работников. И в первом, и во втором случае существует несколько проблем. Одна из них - это обеспечение долговременной сохранности технотронных документов, в частности электронного документа, поскольку сейчас все записи осуществляются с помощью цифровых технологий. Решение проблемы видится в создании отдельных фондов электронных документов, закупке специального оборудования и программного обеспечения, чтобы в будущем информация не была искажена и оставалась читаемой. Нечитаемость информации на электронном носителе может произойти вследствие неблагоприятных условий хранения, а также морального устаревания носителей. Без учета последнего фактора можно столкнуться с тем, что просто будет невозможно воспроизвести информацию, заключенную в том или ином носителе. И здесь приходится еще раз отмечать, что в ведомственные архивы Тувы при организации хранения технотронных документов не учитывают всех факторов. И здесь причина не только в недостатке выделяемых средств, нехватка помещений, специалистов, но и в недостаточном понимании всей серьезности проблемы.

\section{Заключение}

По итогам изучения архивов Тувы были выявлены основные виды технотронных документов, представленные не только как результат документирования деятельности органов государственной власти и управления, местного самоуправления, различных организаций. Огромный пласт кино-фоно-фотодокументов, хранящихся в архивах Тувы, был создан в результате документальной и художественной фотосъемки, документального и художественного кинодокументирования. Также в архивах Тувы хранятся электронные документы. Эти документы тоже нами классифицируются по способу создания: как итог документирования управленческой деятельности, и как результат создания страхового фонда и фонда пользования самого архивного учреждения. Технотронный документ обеспечивает не только связь времен, но и, приоткрывая завесу истории, дает нам возможность в условиях глобализации сохранить национальную идентичность.

Надо уточнить, что технотронные документы хранятся в составе документов фондообразователей, что вызывает определенные сложности не только для исследователя, но и для архивов, поскольку хранение и использование документов, имеющих техническое происхождение, требует создания специальных условий. Результаты исследований показывают, что необходимо проведение комплексных работ, нацеленных не только на выявление технотронных документов архивов Тувы, но и научно-методическое обеспечение организации работы с технотронными документами.

При организации долговременного хранения электронных документов хотелось бы отметить основные направления, которые надо будет учитывать при создании условий. Самое главное - это обеспечение наиболее благоприятных условий для сохранности носителей электронных документов. Здесь речь идет не только о соответствующей температуре и влажности в хранилище, но и физической сохранности носителя (отсутствие царапин, сколов и прочее). В связи с этим надо будет обязательно организовать правильное расположение электронных носителей в хранилище. Одним из серьезных требований для обеспечения долговременной сохранности электронного документа - это создание копий документа и для страхового фонда, и для фонда пользования. Ну и, конечно, с целью предупреждения морального устаревания носителя электронный документ должен регулярно проходить конвертацию на новые носители в новые форматы.

Анализ организации хранения и использования технотронных документов в фондах главного архива Тувы приводит нас к заключению о необходимости образования на базе Государственного архива Республики Тыва Центра хранения технотронных документов.

\section{СПИСОК ЛИТЕРАТУРЫ}

Айыжы, Е. В., Мандан-Хорлу, М. М., Монгуш, А. Ч. (2019а) История создания коллекции В. П. Ермолаева как части этнографического источника изучения материальной и духовной культуры тувинского этноса (часть 1 ) // Oriental Studies. № 44(4). С. 669-681. DOI: 10.22162/2619-0990-2019-44-4-669-681.

Айыжы, Е. В., Мандан-Хорлу, М. М., Монгуш, А. Ч. (2019b) Коллекция В. П. Ермолаева как этнографический источник изучения материальной и духовной культуры тувинского этноса (часть 2) // Oriental Studies. № 45(5). C. 926-937. DOI: 10.22162/2619-0990-2019-45-5-926-937 
Автократов, В. Н. (1978) Фондирование и учет документов (о двух частных теориях архивоведения) // Труды ВНИИДАД. Т. VII. Ч. 1. С. 44-71.

Болтянский, Г. М. (1926) Кинохроника и как ее снимать. М. : Кинопечать. 75 с.

Гедрович, Ф.А. (1998) Технотронные документы - результат технически обусловленных форм письменности // Вестник архивиста. № 2 (44). С. 71-73.

Гедрович, Ф. А., Малышева, Л. Ф. (2005) Рекомендации по организации хранения и методам выявления «уксусного синдрома» оригиналов и страховых копий кинофотофонодокументов и микроформ страхового фонда. М. : Макс-Пресс. 40 с.

Калантарова, Н. А., Алексеева, Т. А. (2011) Из опыта организации работы с аудиовизуальными документами в Российском государственном архиве кинофотодокументов // Вестник архивиста. № 3. С. 70-83.

Кузин, А. А. (1960) Кино-фото- фоноархивы: учебное пособие. М. : МГИАИ. 260 с.

Ланской, Г. Н. (2014) Актуальные проблемы архивоведческого и источниковедческого изучения фотодокументов // Вестник архивиста. № 2. С. 8-17.

Магидов, В. М. (1984) Зримая память истории. М. : Советская Россия. 144 с.

Маковкина, Т. Ю. (2016) Фотодокументы личного происхождения, как часть информационных ресурсов муниципального архива Администрации Аскизского района. // История глазами очевидцев. Материалы I Межрегиональных Архивных чтений / ред. совет: В. М. Райс, И. М. Мироненко. Абакан : Бригантина ООО «Книжное издательство «Бригантина». 204 с. С. 92-99.

Матушевский, Б. (2007) Живая фотография: чем она является и чем должна стать [Электронный текст] // Киноведческие записки. № 83. URL: http://www.kinozapiski.ru/data/home/articles/attache/127-161.pdf (дата обращения: 04.01.2020).

Митяев, К. Г. (1964) Документоведение, его задачи и перспективы развития // Вопросы архивоведения. № 2. C. 27-37.

Моисеева, Р. М. (2006) Фотодокументы по истории войн как объект архивного хранения. // Вестник архивиста. № 6. С. 156-163.

Путеводитель по фондам Государственного архива Республики Тыва за 1715-2011 гг. (2012) / сост. А. М. ДугарСюрюн, Т. А. Бондаренко, М. Ш. Куулар, Н. И. Сургутская. 2 изд., перераб. и доп. Новосибирск : Сибирское кн. издво. 460 c.

Хворова, И. Е. (2017) Процесс оцифровки документов для создания электронного архива [Электронный ресурс] // История и архивы. № 1. С. 22-29. UPL: https://documentation.rsuh.ru/jour/article/view/85/86 (дата обращения: 04.01.2020).

Ховалыг, С. С. (2018) Технотронные архивы России: история и современное состояние // Роль и значение архивов и архивных документов в сохранении исторической памяти народа. Материалы региональной научно-практической конференции, посвященной 100-летию архивной службы России. 26 апреля 2018 г., Республика Тыва, г. Кызыл / отв. ред. Б. В. Мунге. Кызыл : Типография КЦО «Аныяк». 123 с. С. 59-64.

Ховалыг, С. С., Бадыназын, А. А. (2015) Технотронные документы в органах государственной власти Республики Тыва: организация хранения и использование // Делопроизводство. № 4. С. 52-55.

Ховалыг, С. С., Монгуш, Э. О. (2018) Регламентация хранения и использования технотронных документов в ведомственном архиве // Роль и значение архивов и архивных документов в сохранении исторической памяти народа. Материалы региональной научно-практической конференции, посвященной 100-летию архивной службы России. 26 апреля 2018 г., Республика Тыва, г. Кызыл / отв. ред. Б. В. Мунге. Кызыл : Типография КЦО «Аныяк». 123 с. С. $67-71$.

Ховалыг, С. С., Шактар-оол, Ч. Б. (2018) Организация хранения фото- и фонодокументов в Государственном архиве Республики Тыва // Документация в информационном обществе: актуальные проблемы управления электронными документами. Доклады и сообщения XXIV Международной научно-практической конференции (21-22 ноября 2017 г. Москва) / отв. ред. Б. В. Мунге. М. : Росархив, ВНИИДАД. 123 с. С. 322-330.

Хорхордина, Т. И. (2003) Российская наука об архивах: История. Теория. Люди. М. : РГГУ. 535 с.

Шактар-оол, Ч. Б. (2018) Кинодокументы в фондах Государственного архива Республики Тыва: хранение и использование // Роль и значение архивов и архивных документов в сохранении исторической памяти народа. Материалы региональной научно-практической конференции, посвященной 100-летию архивной службы России. 26 апреля 2018 г., Республика Тыва, г. Кызыл / отв ред. Б. В. Мунге. Кызыл : Типография КЦО «Аныяк». 123 с. С. $86-89$.

Дата поступления: 02.02.2020 г.

\section{REFERENCES}

Ayizhy, E., Mandan-Khorlu, M. and Mongush, A. (2019) V. P. Ermolaev's collection as an ethnographic source for studies of Tuvan material and spiritual culture. Part 1. Oriental Studies, no. 44(4), pp. 669-681. (In Russ.) DOI: https://doi. org/10.22162/2619-0990-2019-44-4-669-681 
Ayizhy, E. V., Mandan-Khorlu, M. M., Mongush, A. C. (2019) V. P. Ermolaev’s collection as an ethnographic source for studies of Tuvan material and spiritual culture. Part 2. Oriental Studies, no. 45(5), pp. 926-937. (In Russ.) DOI: https://doi. org/10.22162/2619-0990-2019-45-5-926-937

Avtokratov, V. N. (1978) Fondirovanie i uchet dokumentov (o dvukh chastnykh teoriiakh arkhivovedeniia) [Managing archival collections and documents: On two particular theories in archival studies]. Trudy VNIIDAD, vol. VII, part 1, pp. 44-71. (In Russ.).

Boltianskii, G. M. (1926) Kinokhronika i kak ee snimat' [Newsreel and how to shoot it]. Moscow, Kinopechat'. 75 p. (In Russ.)

Gedrovich, F. A. (1998) Tekhnotronnye dokumenty - rezul'tat tekhnicheski obuslovlennykh form pis'mennosti [Technotronic documents as the result of technically conditioned forms of writing]. Vestnik arkhivista, no. 2 (44), pp. $71-73$. (In Russ.)

Gedrovich, F. A. and Malysheva, L. F. (2005) Rekomendatsii po organizatsii khraneniia i metodam vyiavleniia «uksusnogo sindroma» originalov i strakhovykh kopii kinofotofonodokumentov i mikroform strakhovogo fonda [Recommendations on managing storage and introducing methods for detecting the "vinegar syndrome" in originals and backup copies of video-, photoand phonodocuments and microforms of the reserve stock]. Moscow, Maks-Press. 40 p. (In Russ.)

Kalantarova, N. A. and Alekseeva, T. A. (2011) Iz opyta organizatsii raboty s audiovizual'nymi dokumentami v Rossiiskom gosudarstvennom arkhive kinofotodokumentov [From the experience of working with audiovisual documents in the Russian State Archive of Film and Photo Documents]. Vestnik arkhivista, no. 3, pp. 70-83. (In Russ.)

Kuzin, A. A. (1960) Kino-foto-fonoarkhivy [Video-, photo- and phonoarchives]: textbook. Moscow, MGIAI. 260 p. (In Russ.)

Lanskoi, G. N. (2014) Aktual'nye problemy arkhivovedcheskogo i istochnikovedcheskogo izucheniia fotodokumentov [Urgent issues of archival and source studies of photographic documents]. Vestnik arkhivista, no. 2, pp. 8-17. (In Russ.)

Magidov, V. M. (1984) Zrimaia pamiat' istorii [Visible memory of history]. Moscow, Sovetskaia Rossiia. 144 p. (In Russ.)

Makovkina, T. Yu. (2016) Fotodokumenty lichnogo proiskhozhdeniia, kak chast' informatsionnykh resursov munitsipal'nogo arkhiva Administratsii Askizskogo raiona [Personal photography as part of the information resources of the municipal archive of the Askizsky rayon administration]. In: Istoriia glazami ochevidtsev [History through the eyes of eyewitnesses]. Proceedings of the first Interregional Archival readings / editorial board: V. M. Rais and I. M. Mironenko. Abakan, Brigantina. 204 p. Pp. 92-99. (In Russ.)

Matushevskii, B. (2007) Zhivaia fotografiia: chem ona iavliaetsia i chem dolzhna stat' [Live photography: what it is and what it should become]. Kinovedcheskie zapiski, no. 83 [online] Available at: http://www.kinozapiski.ru/data/home/ articles/attache/127-161.pdf (access date: 04.01.2020). (In Russ.)

Mitiaev, K. G. (1964) Dokumentovedenie, ego zadachi i perspektivy razvitiia [Document studies, its objectives and prospects for development]. Voprosy arkhivovedeniia, no. 2, pp. 27-37. (In Russ.)

Moiseeva, R. M. (2006) Fotodokumenty po istorii voin kak ob"ekt arkhivnogo khraneniia [Photographic documents on the history of wars as an object of archival storage]. Vestnik arkhivista, no. 6, pp. 156-163. (In Russ.)

Putevoditel' po fondam Gosudarstvennogo arkhiva respubliki Tyva [The guide to the collections of the State Archives of the Republic of Tuva] (2012). Ed. by A. M. Dugar-Siuriun, T. A. Bondarenko, M. Sh. Kuular and N. I. Surgutskaia. 2nd ed. Novosibirsk, Sibirskoe knizhnoe izd-vo. 460 p. (In Russ).

Khvorova, I. (2017) Protsess otsifrovki dokumentov dlia sozdaniia elektronnogo arkhiva [The process of digitizing documents in order to create electronic archives]. History and Archives, no. 1, pp. 22-29. (In Russ.)

Khovalyg, S. S. (2018) Tekhnotronnye arkhivy Rossii: istoriia i sovremennoe sostoianie [Technotronic archives of Russia: history and current state]. In: Rol' i znachenie arkhivov i arkhivnykh dokumentov $v$ sokhranenii istoricheskoi pamiati naroda [Role and significance of archives and archival documents in preserving the historical memory of the people]. Proceedings of the regional conference dedicated to the 100th anniversary of the archival service of Russia. April 26, 2018, Republic of Tyva, Kyzyl / ed. by B. V. Munge. Kyzyl, Tipografiia KTsO «Anyiak». 123 p. Pp. 59-64. (In Russ.)

Khovalyg, S. S. and Badynazyn, A. A. (2015) Tekhnotronnye dokumenty v organakh gosudarstvennoi vlasti Respubliki Tyva: organizatsiia khraneniia i ispol'zovanie [Technotronic documents in use by the state authorities of the Republic of Tuva: managing up storage and use]. Deloproizvodstvo, no. 4, pp. 52-55. (In Russ.)

Khovalyg, S. S. and Mongush, E. O. (2018) Reglamentatsiia khraneniia i ispol'zovaniia tekhnotronnykh dokumentov $\mathrm{v}$ vedomstvennom arkhive [Regulation of storage and use of technotron documents in a departmental archive]. In: Rol' $i$ znachenie arkhivov $i$ arkhivnykh dokumentov $v$ sokhranenii istoricheskoi pamiati naroda [Role and significance of archives and archival documents in preserving the historical memory of the people]. Proceedings of the regional conference dedicated to the 100th anniversary of the archive service of Russia. April 26, 2018, Republic of Tyva, Kyzyl / ed. by B. V. Munge. Kyzyl, Tipografiia KTsO «Anyiak». 123 p. Pp. 67-71. (In Russ.)

Khovalyg, S. S. and Shaktar-ool, Ch. B. (2018) Organizatsiia khraneniia foto- i fonodokumentov v Gosudarstvennom arkhive Respubliki Tyva [Managing storage of photo and phonodocuments in the State archive of the Republic of Tuva]. In: Dokumentatsiia $v$ informatsionnom obshchestve: aktual' nye problemy upravleniia elektronnymi dokumentami [Documentation 
in the information society: current problems of electronic document management]. Reports and messages of the XXIV International scientific and practical conference (November 21-22, 2017, Moscow) / ed. by B. V. Munge. Moscow, Rosarkhiv, VNIIDAD. 123 p. Pp. 322-330. (In Russ.)

Khorkhordina, T. I. (2003) Rossiiskaia nauka ob arkhivakh: Istoriia. Teoriia. Liudi [Archival studies in Russia: History. Theory. People]. Moscow, RGGU. 535 p. (In Russ.)

Shaktar-ool, Ch. B. (2018) Kinodokumenty v fondakh Gosudarstvennogo arkhiva Respubliki Tyva: khranenie i ispol'zovanie [Film documents in the collections of the State Archives of the Republic of Tuva: storage and use]. In: Rol' $i$ znachenie arkhivov $i$ arkhivnykh dokumentov $v$ sokhranenii istoricheskoi pamiati naroda [Role and significance of archives and archival documents in preserving the historical memory of the people]. Proceedings of the regional conference dedicated to the 100th anniversary of the archive service of Russia. April 26, 2018, Republic of Tuva, Kyzyl / ed. by B. V. Munge. Kyzyl, Tipografiia KTsO «Anyiak». 123 p. Pp. 86-89. (In Russ.)

Submission date: 02.02.2020. 